\title{
Reading the Message of Feminism in Wonder Woman Film
}

\author{
Daniar Wikan Setyanto ${ }^{1}$, Santosa Soewarlan ${ }^{2}$, Sumbo Tinarbuko ${ }^{3}$ \\ \{daniarwikan@dsn.dinus.ac.id ${ }^{1}$,santosa@isi-ska.ac.id², sumbotinarbuko@gmail.com ${ }^{3}$ \} \\ 1,2 Indonesia Institute Of The Art, Surakarta, Indonesia \\ ${ }^{3}$ Indonesia Institute Of The Art, Yogyakarta, Indonesia
}

\begin{abstract}
Wonder Woman is one of the global feminism icon. The character of Wonder Woman is also the mainstream role model of sexuality ideal for female around the world because she is always displayed attractive either physically or sexually. The idea of gender of discourse representing female in the character of Wonder Woman is not just about idealized (body image) however it is also representing feminism ideology as well as identity politics. The achievement of identity exceeds physical image of women, because in Wonder Woman there are symbols of feminism. This research was done to know what feminism discourse delivered in several scenes and dialogues in the film of Wonder Woman (2017). The method used is descriptive qualitative so that it generates an interpretation which is objective when reading signs system existed in every films of Wonder Woman. The purpose of this study is to look for ideological recomendations for feminism for women as a form of patriarchal propaganda resistance.
\end{abstract}

Keywords: wonder woman, representing, feminism

\section{INTRODUCTION}

Nowadays many studios in Hollywood are starting to boost film production which has the main character of a female hero called Heroine, but the average heroine character in the film does become a minor character (sidekick) and is covered by male superhero characters who are given more appearances. But as the beginning of the heroine revival, the Wonder Woman character was filmed by Warner Bros. in 2017 [1]. Wonder Woman then appeared and manifested everywhere starting from the world of children's entertainment in the form of comics, toys, cartoons, then reaching glass screens and big screens, now the Wonder Woman character even appears in other lines such as fashion, merchandising, artificial games, advertising, even porn sites. In the universe of entertainment, the character of Wonder Woman is an idealized image of women because it is often described as having super powers over ordinary people, intelligent, attractive, visionary, independent, adventurous and active [2]. If we look at it with cultural studies, the attachment of the issues attached to the Wonder Woman character results in the meaning of the ideal female representation, for example in an appearance described as a woman who has perfect physique, beautiful face, ideal body, even attractive attitude. Wonder Woman wraps her body in a costume that explicitly accentuates the sexual attraction in her, namely with a costume design that looks tight and open. Construction 
of the attached physical attraction of Wonder Woman. Although not an ordinary human, Wonder Woman is attached to the symbol of feminism, in other words Wonder Woman is an ideal image of women who globalize, namely an image production that exceeds a certain area of locality. The body of Wonder Woman in the capitalism discourse is not only explored in its use value, but also in its sign value. This image is not only a symptom of capitalism but also a discourse in reconstructing the image or representation of women so that they can be accepted throughout the world to exceed the limit and increase the sale of products that use the image of Wonder Woman [3]. Synnot with his book Social Body, asserts that the human body with its parts has been loaded by cultural, public and private symbolism, positive and negative, political and economic, sexual, and moral which are often controversial [4]. Various kinds of meanings of Wonder Woman are the result of popular culture that is not value-free, with all the potential that exists as a study material for cultural studies researchers specifically feminists relating to women's studies and their implications for women's behaviour [5]. But apparently the representation raises its own problems for women, because for them there is not much choice for them to follow the stereotypical tendencies raised through the media. These problems are increasingly to take form when women's representation is imaged by an overbound fantasy and only exists in a hyper-reality world like the Wonder Woman character. The issue or discourse of women's representation in the Wonder Woman character is certainly not just about an idealized image, especially about body image which may be captured by consumers in plain view by consumers who are not critical [6]. The issue of heroine is more about achieving an identity that exceeds the physical image of women, because in them there are many representations such as class, race, sexuality, globality, and femininity. This research focuses on looking for feminist ideologies that exist in films so that they can complement other findings that discuss a lot of heroism and nationalism in the Wonder Woman character.

Creator of Wonder Woman figure William Moultoni Marston originally designed the character as Suprema because of his fantasies about BDSM (Bondage, Discipline, Dominance, Submission) in sexual activities [7]. But as it went, the character of Suprema finally changed to Wonder Woman in 1941 [8]. Currently the Wonder Woman Character has transformed into the most popular symbol of feminism in the world. This was a breakthrough from Warner Bross, represented by female director Patty Jenkins when directing the Wonder Woman film in 2017 [1]. The selection of the name Wonder Woman indicates that the character is a perfect female mecca as a role model for women in general. Wonder Woman is not only portrayed as a woman who looks perfect, but also extraordinary strength. Having an impressive body Wonder Woman closes it with a tight costume that highlights her body. This study aims to find out the dynamics of signs that exist in the character of Wonder Woman, how the sign works and reconstructs images of representations of the values of globality, class, sexuality, femininity that already exist in our society, thus it is expected to find an ideological notion of feminism in the character of Wonder Woman. Feminism is currently an important study for the community, especially women, the study of feminism often kicks out mass media including films. That makes the messages of feminism in films become discourses in society, thus it is likely to bring changes to society or at least influenced by the social conditions prevailing in the community. Therefore the messages of feminism in the film relate to the role of the female characters that appear in the film. Such conditions make the characters of women in films can be described in many specific roles and functions which show that women can be equal to men even more dominant than men. Along with the passage of time feminism also learns about how women should act and behave in the midst of society [9]. In scientific studies, feminism itself is understood as a movement aimed at determining, building, and maintaining the same political, economic and social rights for women. Feminism supports 
gender equality and considers that humans and the environment are equally important [10]. This study examined the ideological representation of feminism in the character of Wonder Woman in the film and therefore required a visual study of the object. Although it is visual, these signs are also social and psychological or are in the unconscious. Therefore, to analyze, the researcher used the semiotic approach [11]. Wonder Woman is an artificial and imaginative figure, they actually exist in imaginary/fantasy spaces that have excessive traits such as hyper-power and hyper-sexualization if they are seen as the role of a woman. The semiotic approach was used not to spread the raw structure of a standard sign but rather a phenomenon of the operation of ideology in which a marker is produced such as that which is present in the character of Wonder Woman. This approach was suitable because Wonder Woman is more than an imaginary figure because it has a reference to a reality (body) as a biological physical reality of women [12].

\section{METHOD}

Based on the background above, this study used a qualitative descriptive method, namely a research procedure that uses descriptive data in the form of written words (dialogue) and images/visuals (scenes) that can be observed in a film [5]. In the context of this study, the study will investigate feminist ideologies that underlie material in the character of Wonder Woman. The superiority of the qualitative descriptive method is that it can reveal facts, circumstances, and phenomena that occur at the time of research and present data more real. To strengthen the qualitative description method, researchers also used the literature study method [13]. that is by comparing with the findings that appear in the study of film feminism in other books and journals. With this approach, it is expected to produce an objective interpretation when reading the signaling system in each scene in the Wonder Woman film [14].

\section{RESULT AND DISCUSSION}

\subsection{Wonder Woman and Image of Ideal Beauty}

Beautiful besides being identical with the outward (physical) appearance, a woman is also identified with things that are non-physical such as intellectual, character, behavior, achievements and matters relating to human resources. This is of course influenced by several forces that participate in shaping the definition of beauty in mass media, one of which is film. Media construction on a woman's body is the ideal standard for assessing a woman's beauty. The entertainment industry, the advertising industry and beauty products synergize using celebrities by creating beauty myths to be offered to women to reap profits [15]. Essentially Wonder Woman film certainly also has an interest in reconstructing beauty, it functions to expand the perception of women in looking at beauty. As a fictional character, Wonder Woman/Diana Prince has a reality reference, namely the artist who plays the character. The selection of Gal Gadot as the actor of the Wonder Woman figure is certainly through careful consideration, because as a reference to the reality of the figure of Wonder Woman, the representation of Gal Gadot will become a new mecca for the ideal beauty of women throughout the world. The idea of ideal beauty represented by Gal Gadot figures is still physically in the stereotypical beauty of the white race such as tall and thin posture. But the unique thing from the artist Gal Gadot is the relatively small size of her breasts, it had become a pro contra because the four previous Wonder Woman artists had relatively large breasts. Gal Gadot is also the first non-American artist to get the role as Wonder Woman. Gal Gadot was of Jewish descent and an Israeli citizen. This had created controversy because of the tendency 
of the issue of racial representation because in the film Wonder Woman because the film had a World War II setting [16]. Beyond the controversy issue, the selection of Gal Gadot as the representation of women's beauty has brought important ideas where ideal beauty is not just physical beauty but also related to women's resources, this can be seen from the many flashy achievements possessed by the figure of Gal Gadot.

\subsection{Ideology of Feminism in the Wonder Woman Film}

In some scenes in the film Wonder Woman, director Patty Jenkins slipped messages of feminism and its resistance to patriarchal ideology. Here are some examples of scenes in which there are messages of feminism that can be read through the scene and dialogue: The Origin of Amazon (minute 06.18-09.03) that the Amazon tribe was created by a God who was also the god who created humans. The Amazon is a nation that is all female sexually. The gods created the Amazon to restore human nature which had been poisoned by war to full peace and love. Peace is achieved for a while, humans remain full of hatred because of the influence of the god Ares son of Zeus who defected due to envy of humans. After god Ares was conquered by god Zeus then finally the Amazon nation was given a hidden sanctuary from the outside world called Themyscira to remain peaceful and uncontaminated by the wars that existed in the human world. This scene has important issues about women and peace. It is depicted in the origin of Amazon which tells the story of the Amazon tribe who are all female on an island named Themyscira which was originally peaceful before the arrival of Steve Trevor. The Amazon tribe is a symbol of women and its closeness to peace. This scene explicitly also touches on the gender closeness of men with conflicts that exist in the face of the earth and presupposes a fantasy world where there is a place of peace when no man in that place.

Steve's Arrival (minute 15.21-23.09) begins with a scene when a spy named Steve Trevor accidentally enters the Amazon region after his plane was shot by the enemy. Steve Trevor was finally helped by Diana. After Diana helped Steve it turned out that the enemy aircraft group (NAZI) followed Steve from behind and then joined the Amazon region and finally there was a war between the Amazon nation and Nazi forces. The end of this scene was the victory of the Amazon nation and the arrest of Steve Trevor because it was thought to bring conflict into the territory of the Amazon nation. This scene talks about the closeness of a man to a conflict. This can be read from the flow of the scene that shows that Steve Trevor as a representation of men is a figure who brought conflict into Themyscira. The scene was symbolized by a Nazi soldier who chased Steve Trevor to come into Themyscira. This scene continued with a battle between the Amazon people and Nazi forces which, although ended with the victory of the Amazon nation, the conflict claimed many lives from both camps. This initial conflict will later become the entrance for Diana as a Wonder Woman to a much larger scale conflict involving the god Ares as a supervillain.

In The Bathroom (minute 29.45-33.46) was the scene when Diana entered the bathroom right when Steve Trevor was in it still in a naked state. In this scene there is a dialogue packed in comedy, namely when Diana asks Steve "what is that?" And Steve thought that Diana was asking about his penis, but it turned out what Diana meant was a watch next to Steve. This scene was made explicitly, not directly showing the image of Steve Trevor's body that was naked but by means of a medium shoot directing the camera in the upper body but viewers can still read Steve's awkward figure but not trying to cover his body with his hands. This scene contains criticism of the habits of men who make up the genital organs, namely the penis. This scenehas an important message about the patriarchal view of male domination due to sexual function. The message was drawn when Steve thought Diana would be attracted to his penis 
because he was naked. Steve's assumption appeared because he thought Diana had never seen a man before. But it turned out Steve was misunderstood, Diana's question was "what is that?" Referring to the watch beside Steve. Diana even looked totally uninterested in Steve's naked body. Indirectly this scene also contained criticism of the habits of men who tend to sexually exploit the female body because if the situation in the scene was reversed (Steve who went into the bathroom and found Diana naked) then what happened will certainly be very different.

Conversation Steve and Diana on the Ship scene (minute 38.35-43.51) when Diana went along with Steve to find Ares to London. At that time Diana and Steve were in a small boat. During the trip there were several dialogues about the origin of Diana, dialogue about marriage and dialogue about sex. Steve and Diana's dialogue on board when heading to London need to be listened to because it has interesting ideas about marriage and sexuality. The idea of marriage tends to be in the form of criticism which assumes that the marriage has only been a ceremonial administration so far, this was illustrated when Diana asked Steve why people were married when they finally separated and broke their promise to be faithful to death. This dialogue is indirectly a criticism of the high number of divorces throughout the world specifically in America where the marriage procession is no longer something sacred. The scenes and dialogues on the ship also contain socio-cultural criticisms of "sleeping" activities between men and women which are actually not always related to sexual activity. But it is more about the existence of an ethical corridor because these activities are still considered as something that is not polite because of cultural factors. This scene also shows the return of women's passivity to sexuality from Diana's dialogue which seems uninterested even disgusted with the sexual activity that Diana calls "biological reproduction" from a fictional book called Clio. This appears to be inversely proportional to Steve who was curious about the book Clio so Steve hoped Diana took him so he could come read it.

Woman in Parliament (minute 54.23-55.28 and 57.09-59.36) is a scene when Steve entered a parliamentary room where there was a meeting of state officials who were discussing a solution to stop the war. In the room Diana was the only woman. Diana was then pulled out by Steve after being reprimanded by a member of parliament. But in the next Woman in Parliament scene Diana returned to the room with fewer members of parliament. At that time Diana issued her opinion about the war but her opinion was completely ignored by the parliament there and even expelled from parliament. This scene is a depiction of a patriarchal ideology that only recognizes that men alone deserve to sit in a government system and are socially and politically dominant. Moreover, referring to the set time of the film that existed at the end of the First World War in the 1920s where the ideology of feminism had not developed as it is today. Pictured in the scene that every decision and policy related to war is only determined by political elites who are all men. Diana as the only woman in the room was also an "uninvited guest" because Diana entered without permission. The depiction of patriarchy was also very visible when Diana was finally expelled from parliament after expressing her opinion about the war situation that occurred. In the scene, it shows the stereotypes of women of the era who have absolutely no right to speak, let alone make decisions in the system of government.

No Man's Land scene (minute 1.11.41-1.21.27) tells the story of Diana being in a location nicknamed the no man's land, a stretch of land where war between the Nazis and the Allies took place. There Diana was the only woman directly involved in the battlefield. Allied troops were initially in an underground protection area and chose to fight passively because they were outnumbered by Nazi forces. At that time Diana asked them (allies) to attack out actively because Diana could not stand the Nazi policy, but the soldiers refused to even order Diana to remain silent in the bunker for the sake of safety Diana. Finally Diana took the initiative to 
rise to the surface and faced the Nazi army alone. The allied soldiers who were initially afraid finally followed Diana from behind, seeing Diana's greatness in dealing with the Nazis. This scene was closed with the victory of allied soldiers who repelled the Nazis. Diana and her team managed to save a village from the Nazi occupation. This scene is the most extreme depiction of feminism which emphasizes that women are the resolution of conflict, this is certainly a continuation of Steve's Arrival's scene which tends to show the idea that men are a source of conflict in the world. This scene shows the situation of war between Nazi soldiers and allied forces, of course all soldiers in the war were men. There were only a few women in this scene, but the women in this scene were portrayed as nurses and commoners. Only Diana was the only woman directly involved in the conflict. What is unique about this scene is that only Diana has empathy for the victims of war, while the soldiers are only busy with themselves. Indirectly the scene also speaks of the nature of women who are more easily touched when they see the imbalances around them. The scene when Diana finally decides to go into war is the climax of this scene where the scene is a symbol of very strong feminism because it portrays Diana against Nazi forces bravely. When Diana managed to open the way, the allied forces finally flocked behind Diana to fight. This scene shows the situation when a tough woman can finally lead hundreds of men to fight directly against the Nazis and become the solution to the conflict in no man's land.

Feminism represented in the film Wonder Woman actually has several aspects in line with the feminism idea by Y.H Chornelia on leadership patterns and power possessed by women [17], as well as the idea suggested by S.F Siswanto who said that feminism also touches heroism and nationalism existed in women pictured to have power, leadership, heroism and nationalism greater than men[18], however these aspects still need the presence of triggers namely men characters as "love interest". this is pictured at the scene when Wonder Woman finally could got her power out because of her rage after the character of Steve died. Feminism in the film Wonder Woman actually does not describe a figure of "superior" woman in the context of "free of men role" because women still need men's role as the trigger to power and motivation.

\section{CONCLUSION}

The discourse and thought of feminism that emerged in the Wonder Woman character was not only part of the efforts of the mass media to make feminism a global discourse, but also emerged as a result of social facts that developed in the 90 s to the present day where many influential figures emerged and contributed greatly to international and local divisions. The Wonder Woman character is a symbol of the struggle of feminism by actualizing women's dominance in society. A discourse on the women's movement in a film that demands equality of women and men, this film opens a discourse about the shackles of patriarchy laden with male selfishness and becomes a form of patriarchal propaganda resistance. Diana Prince or Wonder Woman characters even though only fictional characters have become a package or products for expressing values of feminist desires that represent women in terms of strength and sexism. If we read the ideology of feminism in the film Wonder Woman (2017), then there is an effort in recommending that women today have to move forward towards the androgin society represented by the character Diana or Wonder Woman. Androgin in this film is a whole human being who is a mixture of positive feminine and masculine qualities. This seems very attached to the figure of Wonder Woman which is actually a combination of two paradoxical elements between feminine and masculine, on the one hand they are strong, good 
at fighting, strong and decisive who represent masculine characteristics, but they are also physically beautiful (sexual) and sympathetic which represents the feminine nature.

\section{REFERENCE}

[1] P. Jenkins, Wonder Woman. USA: Warner Bross, 2017.

[2] R. Schubart, "Bulk, breast, and beauty: negotiating the superhero body in Gal Gadot's Wonder Woman," Continuum (N. Y)., pp. 1-13, 2019.

[3] Audifax, Imagining Lara Croft. Jogjakarta: Jalasutra, 2006.

[4] A. Synnott, "Tomb, temple, machine and self: The social construction of the body," $B r$. J. Sociol., pp. 79-110, 1992.

[5] T. H. N. Rochimah, Pertarungan Wacan Tubuh Perempuan Dalam Media. Jogjakarta: Buku Litera, 2018.

[6] Aquarini Priyatna Prabasmoro, Becoming White, Representasi Ras, Kelas, Femininitas dan Globalitas dalam Iklan Sabun. Jogjakarta: Jalasutra, 2003.

[7] W. M. Marston and H. G. Peter, Wonder woman. Holt, Rinehart and Winston, 1972.

[8] G. Misiroglu and R. David A, The Superhero Book. Los Angeles: Visible Ink Press, 2004.

[9] Rachmah Ida, Studi Media dan Kajian Budaya. Prenada Media Grup, 2014.

[10] Sulastri, "Benturan Budaya Berkomunikasi Dalam Perspektif Gender: Analisis Film Ayat-Ayat Cinta," Kafa'ah J. Gend. Stud., 2011.

[11] S. Tinarbuko, "Membaca Tanda dan Makna Desain Komunikasi Visual," Yogyakarta Badan Penerbit ISI Yogyakarta, 2017.

[12] Y. A. Piliang, Hypersemiotika. Jogjakarta: Jalasutra, 2003.

[13] A. Setiawan, Metodologi Desain. Yogyakarta: Arttex, 2018.

[14] S. Moon, "The Arts, Social Justice, \& Research Methodology," in Three Approaches to Qualitative Research through the ARtS, Brill Sense, 2019, pp. 69-75.

[15] D. W. Setyanto and B. A. P. Adiwibawa, "Membaca Warna Pada Karakter Superhero Marvel," Desain Komun. Vis. Manaj. Desain dan Periklanan, vol. 3, no. 02, pp. 256277, 2018.

[16] J. Selby, "Wonder Woman Gal Gadot on Israel-Gaza: Israeli Actress's pro-IDF Stance Causes Controversy'," Indep., vol. 1, 2014.

[17] Y. H. Chornelia, "Representasi Feminisme Dalam Film 'Snow White and the Huntsman,"' J. e-Komunikasi, vol. 1, no. 3, 2013.

[18] S. F. Siswanto, "Heroism Aspects Of Princess Diana In Patty Jenkin's Wonder Woman." Diponegoro University, 2019. 